Research article

\title{
Altered fractalkine cleavage potentially promotes local inflammation in NOD salivary gland
}

\author{
Manon E Wildenberg, Cornelia G van Helden-Meeuwsen, Hemmo A Drexhage and \\ Marjan A Versnel
}

Department of Immunology, Erasmus MC, P.O. Box 2040, 3000 CA Rotterdam, The Netherlands

Corresponding author: Manon E Wildenberg, m.wildenberg@erasmusmc.nl

Received: 3 Apr 2008 Revisions requested: 15 Apr 2008 Revisions received: 6 May 2008 Accepted: 19 Jun 2008 Published: 19 Jun 2008

Arthritis Research \& Therapy 2008, 10:R69 (doi:10.1186/ar2441)

This article is online at: http://arthritis-research.com/content/10/3/R69

(C) 2008 Wildenberg et al.; licensee BioMed Central Ltd.

This is an open access article distributed under the terms of the Creative Commons Attribution License (http://creativecommons.org/licenses/by/2.0), which permits unrestricted use, distribution, and reproduction in any medium, provided the original work is properly cited.

\begin{abstract}
Introduction In the nonobese diabetic (NOD) mouse model of Sjögren's syndrome, lymphocytic infiltration is preceded by an accumulation of dendritic cells in the submandibular glands (SMGs). NOD mice also exhibit an increased frequency of mature, fractalkine receptor (CX3C chemokine receptor [CX3CR]1) expressing monocytes, which are considered to be precursors for tissue dendritic cells. To unravel further the role played by fractalkine-CX3CR1 interactions in the salivary gland inflammation, we studied the expression of fractalkine in NOD SMGs.

Methods We studied protein expression using Western blot analysis of whole tissue lysates. Protease activity was measured in salivary gland tissue lysates using fluorimetric substrates. Digestive capacity of enzymes was determined by in vitro incubation of recombinant enzyme and fractalkine, followed by protein staining and Western blot.
\end{abstract}

Results Fractalkine was detected in salivary glands of both NOD and control mice at all ages. Western blot analysis showed fractalkine cleavage with increasing age, which was more pronounced in NOD mice. This cleavage resulted in a decrease in the $31 \mathrm{kDa}$ form of the protein, and the generation of an approximately $19 \mathrm{kDa}$ band. Furthermore, in NOD animals older than 15 weeks, we noted the presence of a unique approximately $17 \mathrm{kDa}$ fragment. This cleavage was organ specific, because it did not occur in brain or pancreas. Increased gelatinase and $\alpha$-secretase activity were detected in NOD SMG and contributed to cleavage of the $31 \mathrm{kDa}$ protein. Because aberrant cleavage products may induce autoimmunity, we studied the presence of autoantibodies against fractalkine. Indeed, NOD mice exhibited significantly more antibodies against fractalkine than did control animals.

Conclusion These data indicate that aberrant proteolytic activity in the NOD SMG results in increased fractalkine cleavage and generation of a unique fractalkine fragment. This specific cleavage may contribute to autoimmunity.

\section{Introduction}

The nonobese diabetic (NOD) mouse is a frequently used spontaneous animal model for the development of Sjögren's syndrome $(\mathrm{SjS})$. Similar to SjS patients, these mice develop lymphocytic infiltrates in their salivary glands, which leads to gland destruction and decreased salivary flow. The development of infiltrates is preceded by an accumulation of dendritic cells (DCs). Given the key role played by DCs in the initiation of immune responses, their accumulation as one of the early events in SjS indicates that DCs are involved in the pathogenesis of the disease [1,2]. The precise cause of DC accumulation remains to be elucidated, but alterations in monocytes, which are considered to be a precursor population for DCs, have been described in the NOD mouse $[3,4]$. In particular, the subset of Ly-6Clow monocytes is significantly expanded in the NOD circulation [3]. This subset is thought to be a mature population that preferentially develops into tissue DCs [5], suggesting a link between these cells and the DC accumulation observed in the salivary gland of NOD mice.

Apart from the low expression of $L y-6 C$, the mature monocyte subset is further characterized by low expression of $\mathrm{CC}$ chemokine receptors 1 and 2, and high expression of CX3C chemokine receptor (CX3CR)1, the fractalkine receptor [6]. 
Fractalkine is the sole member of the $\mathrm{CX} 3 \mathrm{C}$ chemokine family, first described in brain tissue [7,8]. It differs from other chemokines not only in its structure and relatively large size, but also in the fact that it occurs in both membrane bound and soluble forms. The membrane bound form functions as an adhesion molecule, whereas the soluble form is strongly chemotactic for monocytes and T cells $[9,10]$.

Given the increase in mature Ly- $6 \mathrm{Cl}^{\text {low }}$ monocytes in the NOD circulation, their propensity to develop into DCs and the importance of fractalkine in chemoattraction of Ly-6Clow monocytes, we studied the expression of fractalkine in NOD salivary glands. Although fractalkine was present in salivary glands of both NOD and control mice, a unique fragment of the protein was observed in NOD mice. Such a fragment may contribute to disruption of tolerance to fractalkine, resulting in an autoimmune response. Indeed, an anti-fractalkine antibody response in the NOD mouse is identified here.

\section{Materials and methods Animals}

NOD/LTj mice were bred in our own facility. Mice were tested for diabetes twice weekly and excluded from experiments when positive. C57BL/6 and BALB/c mice were obtained from Harlan (Horst, The Netherlands). All mice were housed under specific pathogen-free conditions and were fed standard chow and water ad libitum. Female mice aged 5 to 25 weeks were used in all experiments. All experimental procedures were approved by the Erasmus University Animal Ethical Committee.

\section{Tissue lysates and protease activity}

Submandibular glands (SMGs) and pancreases were removed and cleared of adipose tissue and lymph nodes. Tissue was placed in phosphate-buffered saline, or phosphatebuffered saline containing a protease inhibitor cocktail (Complete mini protease inhibitor tablets; Roche, Woerden, The Netherlands) where indicated, and homogenized by mechanical disruption followed by ultrasound sonification. Finally, lysates were cleared by centrifugation. Caspase-3 and gelatinase (matrix metalloprotease [MMP]-2/MMP-9) activity were measured using EnzCheck assay kits (Invitrogen, Eugene, OR, USA) in accordance with the manufacturer's instructions. $\alpha$ Secretase activity was measured using a fluorogenic substrate $(10 \mu \mathrm{g} /$ reaction, alpha-secretase substrate II; Merck, Whitehouse Station, NJ, USA), as indicated by the manufacturer. All results are shown as arbitrary units relative to the total amount of protein, as measured by Bradford analysis (BioRad, Hercules, CA, USA).

\section{Western blot}

Protein content of lysates was measured by Bradford analysis (BioRad) and $50 \mu \mathrm{g}$ of each lysate was loaded onto a $15 \%$ SDS-PAGE gel and run under reducing conditions. For determination of protein size, the Kaleidoscope-prestained stand- ard was used (BioRad). Afterward, protein was transferred to an Immobilon-P membrane (Millipore, Billerica, MA, USA). Membranes were then incubated with anti-fractalkine antibody (C-20, $1 \mu \mathrm{g} / \mathrm{ml}$; Santa Cruz, Santa Cruz, CA, USA) followed by Donkey-anti-Goat-HRP ( $80 \mathrm{ng} / \mathrm{ml}$; Santa Cruz). Expression was detected by enhanced chemiluminescence (ECL) analysis (Amersham, Piscataway, NJ, USA). For detection of autoantibodies, tissue lysates known to contain specific forms of fractalkine were loaded onto a 15\% SDS-PAGE gel. After transfer, membranes were incubated with $\lg$ purified from mouse serum by protein G-column separation or with total serum. This was followed by Rabbit-anti-mouse-HRP (1:20,000; Dako, Glostrup, Denmark) and ECL analysis.

\section{In vitro digestion assay}

MMP-2 (65 ng/reaction; Chemicon, Temecula, CA, USA) and MMP-9 (140 ng/reaction; R\&D Systems Inc., Minneapolis, MN, USA) were activated by $1 \mathrm{mmol} / /$ AMPA in $10 \mathrm{mmol} / \mathrm{l}$ $\mathrm{CaCl}_{2}, 100 \mathrm{mmol} / \mathrm{l} \mathrm{NaCl}$, and $50 \mathrm{mmol} / \mathrm{l}$ (Tris/ $\mathrm{HCl} \mathrm{pH} 7.5$ ). Caspase-3 (10 ng/reaction; Gentaur, Brussels, Belgium) was diluted in $10 \mathrm{mmol} / \mathrm{I}$ PIPES, $2 \mathrm{mmol} / \mathrm{I}$ EDTA, 0.1\% CHAPS and $5 \mathrm{mmol} / \mathrm{DTT}$ ( $\mathrm{pH} \mathrm{7.4)}$. A disintegrin and metalloprotease domain (ADAM)-10 and ADAM-17 (both 500 ng/reaction; R\&D systems Inc.) were diluted in $50 \mathrm{mmol} / \mathrm{l}$ HEPES, $5 \mu \mathrm{mol} /$ $\mathrm{I} \mathrm{ZnCl}_{2}, 0.01 \%$ Brij-0 [pH 7.5]). Enzyme activity was confirmed by fluorimetric assay as described above. Active enzyme was then incubated with brain lysate ( $20 \mu \mathrm{g}$ protein/reaction) for 2 hours at $37^{\circ} \mathrm{C}$. Digestion was stopped by adding reducing sample buffer and heating to $99^{\circ} \mathrm{C}$. Protein analysis was carried out using Western blot as described above.

\section{Statistical analysis}

Bars represent mean, and error bars represent standard deviation. For comparison of means Student's $t$-test was used, and for comparison of frequencies Fisher's exact test was calculated, both using SPSS software (SPSS Inc., Chicago, IL, USA).

\section{Results}

Fractalkine is present in NOD submandibular glands and cleaved with increasing age

To determine the presence of fractalkine at the protein level, expression was studied in SMG tissue lysates by Western blot. Because expression of fractalkine has been clearly described in normal brain [11,12], this was used as a reference sample. Analysis of SMG tissue from young (age 5 weeks) NOD mice revealed expression of the protein at a molecular weight similar to that observed in brain lysates (31 $\mathrm{kDa}$ ). However, when salivary glands of 15 -week-old mice were studied, additional bands were observed at about 19 $\mathrm{kDa}$ and about $17 \mathrm{kDa}$ (Figure 1a). Also, the $31 \mathrm{kDa}$ band was less intense or even undetectable at these time points, indicating cleavage of fractalkine with increasing age in the salivary glands of NOD mice. 
Figure 1

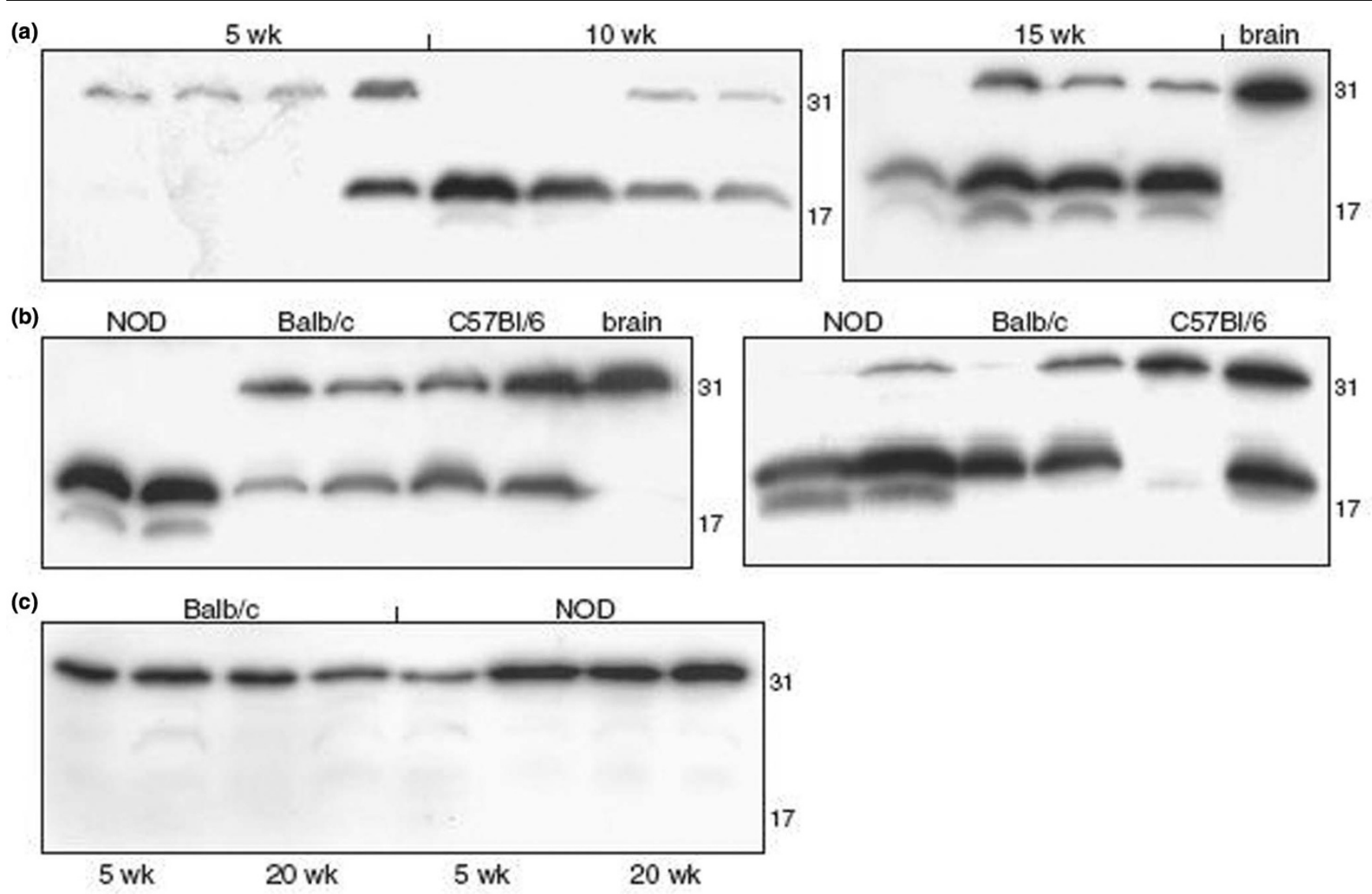

Altered fractalkine cleavage in NOD salivary gland. Whole tissue lysates were prepared in phosphate-buffered saline (PBS) supplemented with protease inhibitor by mechanical homogenization followed by sonification. Lysates were then analysed by Western blotting. A representative picture of six individual experiments is shown. (a) Submandibular gland (SMGs) of 5-, 10- and 15-week-old nonobese diabetic (NOD) mice. (b) SMGs of 10week-old (left) and 20-week-old (right) NOD, C57BL/6 and Balb/c mice. (c) Pancreas of 5- and 20-week-old NOD and Balb/c mice. Numbers represent mass $(\mathrm{kDa})$, as determined using a molecular weight marker.

\section{Fractalkine cleavage is altered in NOD compared with control strains}

When control mice were studied, the profile of fractalkine cleavage differed markedly from that in NOD mice. At age 5 weeks no clear differences were found, with the expression of only the $31 \mathrm{kDa}$ form of the protein in both control strains. At 10 weeks, the approximately $19 \mathrm{kDa}$ band began to appear in C57BL/6 and BALB/c mice. However, whereas expression of the $31 \mathrm{kDa}$ band frequently disappeared in NOD mice at this age, this band was still clearly present in the control strains (Figure 1b). The additional approximiately $17 \mathrm{kDa}$ form of fractalkine, which was found in NOD mice, never appeared in either $\mathrm{C} 57 \mathrm{BL} / 6$ or BALB/c mice at any time point up to 20 weeks (Figure 1b). These results indicate that the profile of the cleavage process differs between NOD and control strains, and that the specific cleavage in NOD SMG results in the generation of a unique fractalkine fragment in the NOD mouse.
Cleavage of fractalkine does not occur in NOD pancreas The NOD mouse not only develops sialoadenitis but also autoimmune insulitis. Similar to the salivary glands, lymphocytic infiltration in the pancreas is preceded by an accumulation of DCs. Because the sialoadenitis and pancreatitis observed in NOD mice are usually considered to be the result of at least partly overlapping defects, expression of fractalkine in the pancreas was studied and compared with that of the SMG. In both NOD and control mice, expression of the $31 \mathrm{kDa}$ form of fractalkine was detected at all ages tested. However, smaller products were not observed at any age, either in NOD or in the control strains (Figure 1c). This indicates that the increase in protease activity is SMG specific.

\section{ADAM-17 induces fractalkine cleavage, but ADAM-10 and caspase-3 do not}

Altered protein breakdown has previously been described in the SMG of NOD mice, a specific example being the autoantigen $\alpha$-fodrin, and this was linked to caspase-3 activity [1315]. Therefore, caspase- 3 activity was measured in whole 
Figure 2
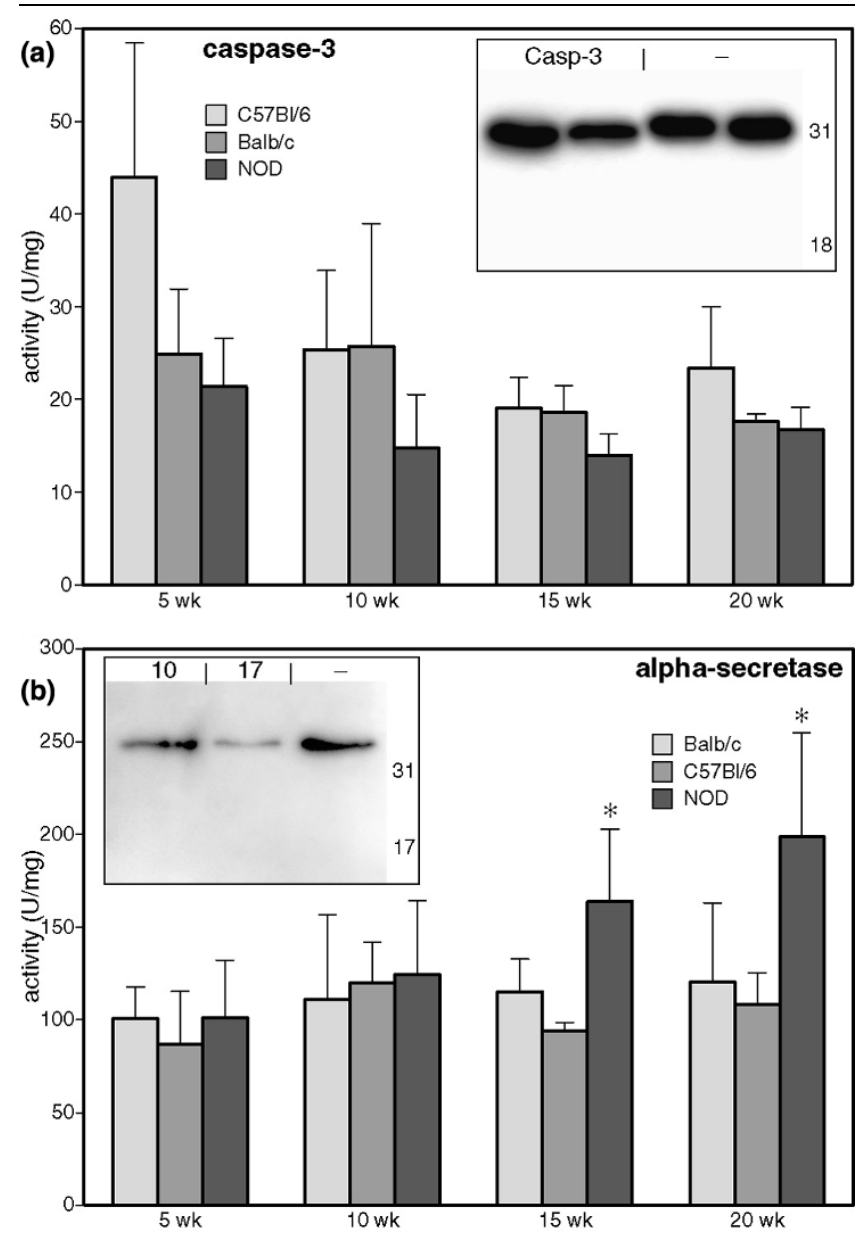

ADAM-1 7 but not caspase-3 cleaves $31 \mathrm{kDa}$ fractalkine. (a) Caspase3 and (b) $\alpha$-secretase activities were measured in tissue lysates prepared in phosphate-buffered saline without protease inhibitors using a fluorimetric assay. Bars represent mean, error bars represent standard deviation $(n=5)$. * $P<0.05$. Recombinant mouse caspase-3 (panel a) and a disintegrin and metalloprotease domain (ADAM)-10 or -17 (panel b) were incubated with brain lysate and analysed by Western blotting $(n=4)$. Numbers represent mass $(\mathrm{kDa})$, as determined using a molecular weight marker.

salivary gland lysates. Although activity could be detected at all ages, no increase in caspase-3 activity was observed in the NOD mouse (Figure 2a). Furthermore, when brain lysates containing the $31 \mathrm{kDa}$ form of fractalkine were incubated with recombinant caspase-3, no digestion of fractalkine was observed (Figure 2a [insert]).

Another family of proteases involved in regulating fractalkine levels are the so-called $\alpha$-secretases. These include ADAM-10 and ADAM-17, which have been shown to cleave fractalkine under steady-state and inflammatory conditions, respectively $[16,17]$. When measured in whole salivary gland lysates, $\alpha$ secretase activity was significantly increased in NOD mice from the age of 15 weeks onward (Figure 2b). When incubated with brain lysate in vitro, ADAM-17 but not ADAM-10 was capable of cleaving $31 \mathrm{kDa}$ fractalkine. However, the approximately 19 and $17 \mathrm{kDa}$ bands did not appear (Figure $2 \mathrm{~b}$ [insert]), and neither did any smaller fractalkine fragments down to $6 \mathrm{kDa}$ (data not shown). This indicates that although ADAM-17 may contribute to the fractalkine cleavage observed in NOD SMG, other proteases probably result in the generation of the approximately $19 \mathrm{kDa}$ and $17 \mathrm{kDa}$ fragments.

\section{MMP-9 activity leads to cleavage of $31 \mathrm{kDa}$ fractalkine}

Increased expression of MMP-9 has been described in the salivary glands of SjS patients, and RNA levels of both MMP-2 and MMP-9 are increased in the SMG of NOD mice [18-20]. Because fractalkine has been shown to be a ligand for MMP2 [21], increased activity of these metalloproteases may be involved in the altered proteolysis of fractalkine. When measured in whole salivary gland lysates, gelatinase (combined MMP-2 and MMP-9) activity was increased in NOD mice aged 10 weeks - the time point at which the increased cleavage of fractalkine in the NOD first becomes apparent (Figure 3a). Furthermore, incubation of brain lysates with recombinant MMP9 , but not with MMP-2, resulted in a clear reduction in the 31 $\mathrm{kDa}$ form of fractalkine (Figure $3 \mathrm{~b}$ ). However, the approximately 19 and $17 \mathrm{kDa}$ bands did not appear in this experiment, and neither did any smaller fragments down to $6 \mathrm{kDa}$ (data not shown). This indicates that in addition to MMP-9, other proteases are likely to contribute to the fractalkine cleavage observed in vivo.

\section{Presence of autoantibodies against fractalkine in NOD}

Altered proteolysis of $\alpha$-fodrin in NOD results in the generation of an autoantigen and the formation of autoantibodies [14]. Therefore, the occurrence of autoantibodies against fractalkine was studied by testing the reactivity of mouse serum with blotted brain lysate containing the $31 \mathrm{kDa}$ form of fractalkine. In the serum of young ( 5 weeks) animals, reactivity against the $31 \mathrm{kDa}$ protein could not be detected. However, in the serum of animals older than 15 weeks, antibodies against a protein running at $31 \mathrm{kDa}$ were detected in 10 out of 14 NOD mice (Figure 4). In control animals, this was the case in significantly fewer (one out of six; $P<0.05$ ). Similar results were obtained with purified IgG and total serum (data not shown). Fractalkine specificity of the anti-31 kDa band was confirmed by blotting against recombinant fractalkine (data not shown). These results indicate that fractalkine indeed becomes an autoantigen in the NOD mouse.

\section{Discussion}

NOD mice exhibit an abnormal breakdown of fractalkine in salivary glands, which results in the generation of a unique fragment. This breakdown did not occur in pancreas, indicating that the phenomenon is organ specific and not a result of local inflammation. Altered proteolytic cleavage in NOD salivary glands has previously been described for $\alpha$-fodrin and parotid secretory protein $[13,14,22,23]$. In the case of $\alpha$-fodrin, proteolysis is caused by the apoptotic enzyme caspase-3 [13] 
Figure 3

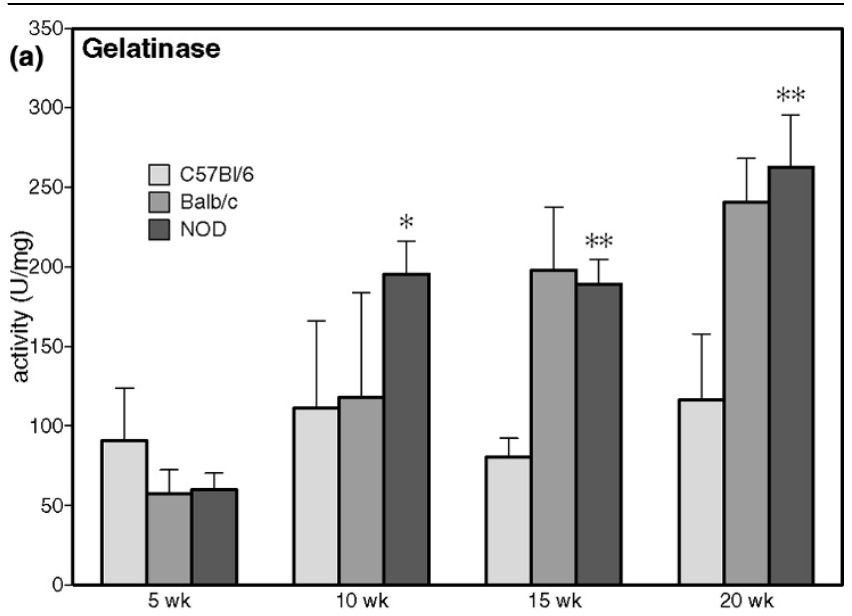

(b)

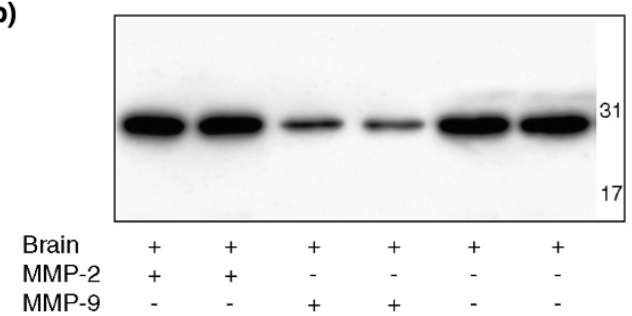

MMP-9 cleaves $31 \mathrm{kDa}$ in vitro. (a) Gelatinase activity was measured in tissue lysates prepared in phosphate-buffered saline without protease inhibitors using a fluorimetric assay; bars represent mean, and error bars represent standard deviation. ${ }^{\star} P<0.05$ versus $\mathrm{C} 57 \mathrm{BL} / 6$ and Balc/c; ${ }^{\star \star} P<0.05$ versus C57BL/6 $(n=5)$. (b) Recombinant mouse matrix metalloprotease (MMP)-2 and MMP-9 were incubated with brain lysate and analysed by Western blotting $(n=3)$. Numbers represent mass $(\mathrm{kDa})$, as determined using a molecular weight marker.

Although caspase-3 was detected in SMGs from mice of all ages, activity was not increased in NOD compared with control animals. Furthermore, caspase-3 did not cleave $31 \mathrm{kDa}$ fractalkine in vitro. Two proteases described to be involved in the physiological shedding of fractalkine are ADAM-10 and ADAM-17 [16,17]. However, although the joint activity of these enzymes did increase in NOD mice at older ages $(>15$ weeks) and ADAM-17 was capable of cleaving $31 \mathrm{kDa}$ fractalkine in vitro, this did not results in the generation of the approximately 19 and $17 \mathrm{kDa}$ bands.

Previous reports describe the abnormal breakdown of extracellular matrix components in SjS salivary glands, and this was linked to increased activity of MMPs [24]. In particular, expression of MMP-9 has consistently been found to be increased in salivary glands of SjS patients. In NOD mice, increased expression of this metalloprotease in SMG was reported in old (> 20 weeks) animals [18-20,24-27]. Our study shows that MMP-9 activity has already increased at around 10 weeks of age, similar to the time point at which cleavage of fractalkine was first observed. Additionally, MMP-9 has been shown to be capable of degrading the $31 \mathrm{kDa}$ form of fractalkine. However, the characteristic approximately 17 and $19 \mathrm{kDa}$ forms did not
Figure 4

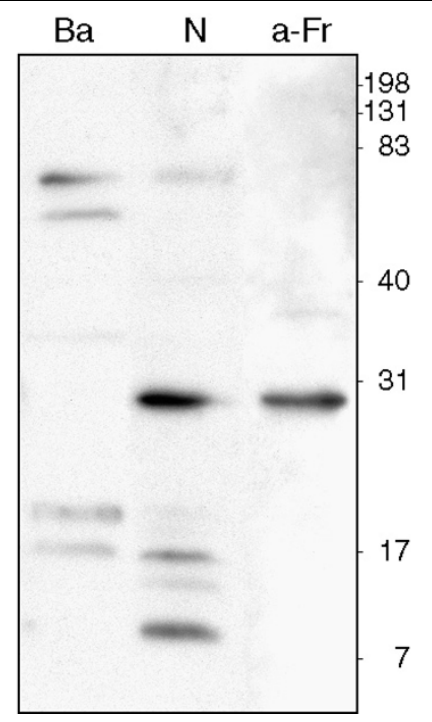

Autoantibodies against fractalkine are present in NOD mice. Tissue lysates prepared in phosphate-buffered saline supplemented with protease inhibitors were run on an SDS gel and transferred to an Immobilon membrane (Millipore, Billerica, MA, USA). Membranes were then incubated with purified lgG from either NOD $(\mathrm{N})$ or Balb/c $(\mathrm{Ba})$ mice. Binding of autoantibodies was detected by anti-mouse-HRP and electrochemical luminescence (ECL) analysis. Presence of specific fractalkine fragments in the lysate was detected using a polyclonal antifractalkine antibody (a-Fr). Numbers represent mass $(\mathrm{kDa})$, as determined using a molecular weight marker.

appear. When fractalkine was incubated with MMP-9 and analyzed by total protein staining, neither the approximately 19 and $17 \mathrm{kDa}$ fragments nor smaller fragments were detected (data not shown). This suggests that MMP-9 cleavage results in very small fragments, at least in vitro. Hence, although both ADAM-17 and MMP-9 are involved in the degradation of fractalkine, other proteases are likely to be responsible for the generation of the approximately 19 and $17 \mathrm{kDa}$ fragments in vivo. Candidates for this function include members of the caspase family, such as caspase- 1 and caspase-11, both of which are increased in the salivary glands under inflammatory conditions $[28,29]$. Also, granzyme B may be involved, because this protease has been shown to generate antigenic fragments by cleaving $\alpha$-fodrin, La protein and muscarinic receptor 3 $[30,31]$, all of which are known autoantigens in SjS.

The precise nature of the fractalkine fragments described in this study remains to be further elucidated. Attempts to isolate the fractalkine fragments from SMG lysates were unsuccessful because of the abundant presence of other proteins in the total gland lysates. However, the antibody used to detect fractalkine in this study recognizes the carboxyl-terminal end, indicating that both the approximately 19 and $17 \mathrm{kDa}$ fragments contain this part of the protein. One hypothesis is that the approximately 19 and $17 \mathrm{kDa}$ fragments are the remaining (carboxyl-terminal) fragments after shedding of the amino-terminal part of the protein. This amino-terminal part contains the 
chemokine domain, which in this model could be released into the circulation and enhance monocyte chemoattraction to the salivary glands. Previous studies have shown that fractalkine is indeed a substrate for metalloproteinases, resulting in the generation of a highly active chemotactic fragment [32]. Interestingly, the fractalkine receptor positive population of Ly-6Clow monocytes is increased significantly in NOD mice [3]. This population preferentially develops in tissue DCs [33], and fractalkine receptor positive cells resembling DCs were observed in murine salivary glands (HC Reinecker, personal communication). This supports the idea of chemotactic fractalkine contributing to the accumulation of DCs in NOD salivary glands. To investigate further this contribution, it would be interesting to cross CX3CR1-deficient mice [34] back to the NOD background, and determine the effect on monocyte infiltration and DC accumulation.

In the case of $\alpha$-fodrin, the altered cleavage in $\mathrm{pSjS}$ and NOD salivary glands results in an autoantigenic protein and the generation of autoantibodies as well as a specific T-cell response $[14,35]$. Importantly, when cleavage of $\alpha$-fodrin is inhibited, pathology is prevented [36], indicating the significance of this process. In this study we showed that the abnormal cleavage of fractalkine is also accompanied by the occurrence of autoantibodies. In NOD mice, antibodies recognizing $31 \mathrm{kDa}$ fractalkine were present from about 10 weeks and increased with age. In control mice, these autoantibodies were found in significantly fewer animals, and at lower concentrations. It is tempting to speculate that the abnormal breakdown of fractalkine in NOD SMG contributes to a break of tolerance against this self protein, thus resulting in the formation of autoantibodies. The source of fractalkine in the NOD SMG remains to be elucidated, but studies in human salivary gland show that fractalkine is expressed in glandular epithelium as well as ductal structures [37]. An anti-fractalkine response would therefore be targeted directly against the salivary gland epithelium, and contribute to destruction of the salivary gland tissue.

\section{Conclusion}

Increased proteolytic activity in the salivary gland of NOD mice leads to the generation of aberrant fractalkine fragments. These may enhance the ongoing inflammation by functioning as autoantigens. Furthermore, the enhanced cleavage of fractalkine is hypothesized to result in increased chemotaxis. This dual role for fractalkine in local inflammation in SjS salivary glands indicates that fractalkine may be an interesting target for future therapy.

\section{Competing interests}

The authors declare that they have no competing interests.

\section{Authors' contributions}

MEW designed the study, carried out the protease activity assays and was responsible for writing of the manuscript.
CvHM carried out the Western Blot experiments and revised the Materials and methods section of the manuscript. HAD provided critical revisions to the manuscript. MAV directed the project and provided critical revisions of the manuscript. All authors read and approved the final manuscript.

\section{Acknowledgements}

The authors would like to thank $\operatorname{Dr} C$ Cheng (Department of Cardiology, Erasmus MC, The Netherlands) for performing initial RQ-PCR experiments and Dr HC Reinecker (Gastrointestinal Unit, Massachusetts General Hospital and Harvard Medical School, MA, USA) for evaluation of fractalkine receptor expression in mouse salivary gland. This study was funded by the Erasmus University, Rotterdam, The Netherlands.

\section{References}

1. van Blokland SC, van Helden-Meeuwsen CG, Wierenga-Wolf AF, Drexhage HA, Hooijkaas H, Merwe JP van de, Versnel MA: Two different types of sialoadenitis in the NOD- and MRL/lpr mouse models for Sjögren's syndrome: a differential role for dendritic cells in the initiation of sialoadenitis? Lab Invest 2000, 80:575-585.

2. van Blokland SC, Wierenga-Wolf AF, van Helden-Meeuwsen CG, Drexhage HA, Hooijkaas H, Merwe JP van de, Versnel MA: Professional antigen presenting cells in minor salivary glands in Sjögren's syndrome: potential contribution to the histopathological diagnosis? Lab Invest 2000, 80:1935-1941.

3. Nikolic T, Bouma G, Drexhage HA, Leenen PJ: Diabetes-prone NOD mice show an expanded subpopulation of mature circulating monocytes, which preferentially develop into macrophage-like cells in vitro. J Leukoc Biol 2005, 78:70-79.

4. Nikolic T, Bunk M, Drexhage HA, Leenen PJ: Bone marrow precursors of nonobese diabetic mice develop into defective macrophage-like dendritic cells in vitro. J Immunol 2004, 173:4342-4351.

5. Sunderkotter C, Nikolic T, Dillon MJ, Van Rooijen N, Stehling M, Drevets DA, Leenen PJ: Subpopulations of mouse blood monocytes differ in maturation stage and inflammatory response. $J$ Immunol 2004, 172:4410-4417.

6. Geissmann F, Jung S, Littman DR: Blood monocytes consist of two principal subsets with distinct migratory properties. Immunity 2003, 19:71-82.

7. Rossi DL, Hardiman G, Copeland NG, Gilbert DJ, Jenkins N, Zlotnik A, Bazan JF: Cloning and characterization of a new type of mouse chemokine. Genomics 1998, 47:163-170.

8. Bazan JF, Bacon KB, Hardiman G, Wang W, Soo K, Rossi D, Greaves DR, Zlotnik A, Schall TJ: A new class of membranebound chemokine with a CX3C motif. Nature 1997, 385:640-644.

9. Imai T, Hieshima K, Haskell C, Baba M, Nagira M, Nishimura M, Kakizaki M, Takagi S, Nomiyama H, Schall TJ, Yoshie O: Identification and molecular characterization of fractalkine receptor CX3CR1, which mediates both leukocyte migration and adhesion. Cell 1997, 91:521-530.

10. Ancuta P, Rao R, Moses A, Mehle A, Shaw SK, Luscinskas FW, Gabuzda D: Fractalkine preferentially mediates arrest and migration of $\mathrm{CD}^{+} 6^{+}$monocytes. J Exp Med 2003, 197:1701-1707.

11. Tarozzo G, Bortolazzi S, Crochemore C, Chen SC, Lira AS, Abrams JS, Beltramo M: Fractalkine protein localization and gene expression in mouse brain. J Neurosci Res 2003, 73:81-88.

12. Hatori K, Nagai A, Heisel R, Ryu JK, Kim SU: Fractalkine and fractalkine receptors in human neurons and glial cells. J Neurosci Res 2002, 69:418-426.

13. Miyazaki K, Takeda N, Ishimaru N, Omotehara F, Arakaki R, Hayashi $\mathrm{Y}$ : Analysis of in vivo role of alpha-fodrin autoantigen in primary Sjögren's syndrome. Am J Pathol 2005 167:1051-1059.

14. Yanagi K, Ishimaru N, Haneji N, Saegusa K, Saito I, Hayashi Y: Anti-120-kDa alpha-fodrin immune response with Th1cytokine profile in the NOD mouse model of Sjögren's syndrome. Eur J Immunol 1998, 28:3336-3345. 
15. Wang $Y$, Virji AS, Howard $P$, Sayani $Y$, Zhang J, Achu P, McArthur C: Detection of cleaved alpha-fodrin autoantigen in Sjögren's syndrome: apoptosis and co-localisation of cleaved alphafodrin with activated caspase-3 and cleaved poly(ADP-ribose) polymerase (PARP) in labial salivary glands. Arch Oral Biol 2006, 51:558-566.

16. Garton KJ, Gough PJ, Blobel CP, Murphy G, Greaves DR, Dempsey PJ, Raines EW: Tumor necrosis factor-alpha-converting enzyme (ADAM17) mediates the cleavage and shedding of fractalkine (CX3CL1). J Biol Chem 2001, 276:37993-38001.

17. Hundhausen C, Misztela D, Berkhout TA, Broadway N, Saftig P, Reiss K, Hartmann D, Fahrenholz F, Postina R, Matthews V, Kallen KJ, Rose-John S, Ludwig A: The disintegrin-like metalloproteinase ADAM10 is involved in constitutive cleavage of CX3CL1 (fractalkine) and regulates $\mathrm{CX} 3 \mathrm{CL} 1$-mediated cell-cell adhesion. Blood 2003, 102:1186-1195.

18. Asatsuma $M$, Ito $S$, Watanabe $M$, Takeishi $H$, Nomura $S$, Wada $Y$, Nakano $M$, Gejyo $F$, Igarashi $A$ : Increase in the ratio of matrix metalloproteinase- 9 to tissue inhibitor of metalloproteinase-1 in saliva from patients with primary Sjögren's syndrome. Clin Chim Acta 2004, 345:99-104.

19. Konttinen YT, Halinen S, Hanemaaijer R, Sorsa T, Hietanen J, Ceponis A, Xu JW, Manthorpe R, Whittington J, Larsson A, Salo T, Kjeldsen L, Stenman UH, Eisen AZ: Matrix metalloproteinase (MMP)-9 type IV collagenase/gelatinase implicated in the pathogenesis of Sjögren's syndrome. Matrix Biol 1998, 17:335-347.

20. Yamachika S, Nanni JM, Nguyen KH, Garces L, Lowry JM, Robinson CP, Brayer J, Oxford GE, da Silveira A, Kerr M, Peck AB, Humphreys-Beher MG: Excessive synthesis of matrix metalloproteinases in exocrine tissues of NOD mouse models for Sjögren's syndrome. J Rheumatol 1998, 25:2371-2380.

21. Dean RA, Overall CM: Proteomics discovery of metalloproteinase substrates in the cellular context by iTRAQ labeling reveals a diverse MMP-2 substrate degradome. Mol Cell Proteomics 2007, 6:611-623.

22. Haneji N, Nakamura T, Takio K, Yanagi K, Higashiyama H, Saito I, Noji S, Sugino $\mathrm{H}$, Hayashi $\mathrm{Y}$ : Identification of alpha-fodrin as a candidate autoantigen in primary Sjögren's syndrome. Science 1997, 276:604-607.

23. Robinson CP, Yamamoto $H$, Peck AB, Humphreys-Beher MG: Genetically programmed development of salivary gland abnormalities in the NOD (nonobese diabetic)-scid mouse in the absence of detectable lymphocytic infiltration: a potential trigger for sialoadenitis of NOD mice. Clin Immunol Immunopathol 1996, 79:50-59.

24. Goicovich E, Molina C, Perez P, Aguilera S, Fernandez J, Olea N, Alliende C, Leyton C, Romo R, Leyton L, González MJ: Enhanced degradation of proteins of the basal lamina and stroma by matrix metalloproteinases from the salivary glands of Sjögren's syndrome patients: correlation with reduced structural integrity of acini and ducts. Arthritis Rheum 2003, 48:2573-2584.

25. Perez P, Goicovich E, Alliende C, Aguilera S, Leyton C, Molina C, Pinto R, Romo R, Martinez B, Gonzalez MJ: Differential expression of matrix metalloproteinases in labial salivary glands of patients with primary Sjögren's syndrome. Arthritis Rheum 2000, 43:2807-2817.

26. Perez $\mathrm{P}, \mathrm{K}$ won $\mathrm{YJ}$, Alliende $\mathrm{C}$, Leyton L, Aguilera S, Molina C, Labra C, Julio M, Leyton C, Gonzalez MJ: Increased acinar damage of salivary glands of patients with Sjogren's syndrome is paralleled by simultaneous imbalance of matrix metalloproteinase $3 /$ tissue inhibitor of metalloproteinases 1 and matrix metalloproteinase $9 /$ tissue inhibitor of metalloproteinases 1 ratios. Arthritis Rheum 2005, 52:2751-2760.

27. Yamachika S, Brayer J, Oxford GE, Peck AB, Humphreys-Beher MG: Aberrant proteolytic digestion of biglycan and decorin by saliva and exocrine gland lysates from the NOD mouse model for autoimmune exocrinopathy. Clin Exp Rheumatol 2000, 18:233-240.

28. Ishimaru N, Arakaki R, Watanabe M, Kobayashi M, Miyazaki K, Hayashi Y: Development of autoimmune exocrinopathy resembling Sjögren's syndrome in estrogen-deficient mice of healthy background. Am J Patho/ 2003, 163:1481-1490.

29. Killedar SJ, Eckenrode SE, Mclndoe RA, She JX, Nguyen CQ, Peck $A B$, Cha S: Early pathogenic events associated with Sjö- gren's syndrome (SjS)-like disease of the NOD mouse using microarray analysis. Lab Invest 2006, 86:1243-1260.

30. Nagaraju K, Cox A, Casciola-Rosen L, Rosen A: Novel fragments of the Sjögren's syndrome autoantigens alpha-fodrin and type 3 muscarinic acetylcholine receptor generated during cytotoxic lymphocyte granule-induced cell death. Arthritis Rheum 2001, 44:2376-2386.

31. Huang $\mathrm{M}$, Ida $\mathrm{H}$, Kamachi M, Iwanaga $\mathrm{N}$, Izumi $\mathrm{Y}$, Tanaka $\mathrm{F}$, Aratake K, Arima K, Tamai M, Hida A, Nakamura H, Origuchi T, Kawakami A, Ogawa N, Sugai S, Utz PJ, Eguchi K: Detection of apoptosisspecific autoantibodies directed against granzyme B-induced cleavage fragments of the SS-B (La) autoantigen in sera from patients with primary Sjögren's syndrome. Clin Exp Immunol 2005, 142:148-154.

32. Overall CM, Dean RA: Degradomics: systems biology of the protease web. Pleiotropic roles of MMPs in cancer. Cancer Metastasis Rev 2006, 25:69-75.

33. Randolph GJ, Sanchez-Schmitz G, Liebman RM, Schakel K: The

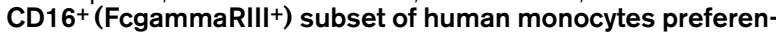
tially becomes migratory dendritic cells in a model tissue setting. J Exp Med 2002, 196:517-527.

34. Haskell CA, Hancock WW, Salant DJ, Gao W, Csizmadia V, Peters W, Faia K, Fituri O, Rottman JB, Charo IF: Targeted deletion of CX(3)CR1 reveals a role for fractalkine in cardiac allograft rejection. J Clin Invest 2001, 108:679-688.

35. Watanabe T, Tsuchida T, Kanda N, Mori K, Hayashi Y, Tamaki K: Anti-alpha-fodrin antibodies in Sjögren syndrome and lupus erythematosus. Arch Dermatol 1999, 135:535-539.

36. Saegusa K, Ishimaru N, Yanagi K, Mishima K, Arakaki R, Suda T, Saito I, Hayashi Y: Prevention and induction of autoimmune exocrinopathy is dependent on pathogenic autoantigen cleavage in murine Sjögren's syndrome. J Immunol 2002, 169:1050-1057.

37. Latchney LR, Fallon MA, Culp DJ, Gelbard HA, Dewhurst S: Immunohistochemical assessment of fractalkine, inflammatory cells, and human herpesvirus $\mathbf{7}$ in human salivary glands. $J$ Histochem Cytochem 2004, 52:671-681. 